\title{
Freud's Theory and the Group Mind Theory: Formulations
}

\author{
Claudio Garcia Capitão* \\ São Francisco University, Rua Alexandre Rodrigues Barbosa, Itatiba, Brazil \\ Email: cgcapitao@uol.com.br
}

Received October 2, 2013; revised November 2, 2013; accepted November 10, 2013

Copyright (C) 2014 Claudio Garcia Capitão. This is an open access article distributed under the Creative Commons Attribution License, which permits unrestricted use, distribution, and reproduction in any medium, provided the original work is properly cited. In accordance of the Creative Commons Attribution License all Copyrights (C) 2014 are reserved for SCIRP and the owner of the intellectual property Claudio Garcia Capitão. All Copyright (c) 2014 are guarded by law and by SCIRP as a guardian.

\section{ABSTRACT}

This study aimed to reconsider some concepts of the psychoanalytic theory on group mind. Group psychology is concerned with the individual man as a member of a race, nation, caste, profession, or an institution, or as a component of a crowd of people that has been organized into a group at some particular time, for some specific purpose. Group psychology embraces an immense number of separate issues and offers investigators with countless problems, which have hitherto not even been properly distinguished from one another. Reflections presented in this paper were particularly inspired by Freud's work on Group psychology and analysis of the ego and approaches to the chaos theory, especially, the fact that groups emerge as systems that exhibit unstable, aperiodic and highly complex behavior, with a tendency to self-organization.

\section{KEYWORDS}

\section{Group Phenomena; Psychoanalytic Theory; Identification; Chaos Theory}

\section{Introduction}

For Freud [1], libidinal relations determine the Group phenomena and are also the basis of the enigmatic suggestive process. He does not consider it as the case of sexual relations established between the group members. On the contrary, if there would have been sex/sexual intercourse, then the group would not work as such. Libido refers to the sexual energy, desire for sexual activity, or the representative of Eros. On the other hand, love basically represents the things, which are in a sphere: the fraternal love, the love for wisdom, for the preservation of nature, for people, for oneself, etc. The libido, as sexual energy, can nonetheless suffer inhibition, or misappropriation of its purposes. Therefore, there can be desexualized friendships i.e., friendship between men and men, women and women, women and men and vice versa, because libido can be sublimated and shifted to a

\footnotetext{
*Psychologist and psychoanalyst, with specialization in clinical psychology and in Hospital psychology. Presently teaches graduation and post-graduation courses full time in São Francisco University, São Paulo, Brazil. He works as psychologist in the Institute of Infectious Disease Emilio Ribas attending to patient bearing HIV/AIDS.
}

purpose other than being exclusively sexual in nature.

Libido is an expression that is derived from the theory of emotions. This name is given to the energy, which is regarded as a quantitative magnitude (though it cannot be measured in reality) of those instincts that can be covered by love. The core of what we refer to as love is actually (and this is what is commonly called love and poets sing) sexual love, i.e., love that aims sexual intercourse as a goal. However, this concept does not isolate the fact that love, on one hand, is self-love and on the other hand, is the love for parents and children, love for mankind in general, as well as devotion for materialistic objects and abstract ideas. Our justification is based on the fact that psychoanalytic research has taught us that all these tendencies constitute the expression of the same instinctual impulses, i.e., relations between sexes. These impulses force their way toward the goal of sexual union, but in some other circumstances, are diverted from the goal or are prevented from reaching it, even if, the impulses always retain enough of their original nature to maintain recognizable identity (as in characteristics such as, longing for closeness and self-sacrifice) [1-4]. Libido is also 
considered as a representative of Eros, which means life pulsion.

Freud presents [5] a theoretical assumption regarding the origin of life and death. His essay, "Beyond the Pleasure Principle", asserts that the inanimate matter undergoes a tensioning, and at that moment, life comes into origin/existence. Cells require grouping, which makes the tissue more resistant, thus prolonging the state of tension for a longer duration, which consequently leads to the origin of life. An example of cell grouping can be found in the formation of epithelial tissue. Each cell that constitutes the skin has different consistency and composes the skin separately.

A very similar reasoning is applied by Freud to the formation of groups. Eros or life pulsion means what agglutinates or which is responsible for growth; Thanatos or death pulsion is what separates or which is responsible for separation. For example, after one's death the cells disintegrate and die. When we talk about someone destructive, we mean a person who destroys or separates. So, romantic relationships are those that tend to make people closer, linking them through emotional ties of love. This fact for Freud is exactly the essence of group mind and the way in which the group is shaped [5].

With these theoretical arguments in mind, Freud began to analyze two very interesting and peculiar organizations: the Church and the Army, which are essentially paradigmatic that permeate and encompass much of the human history [5-7].

The Church and the Army are not natural organizations, for example like a family. These are artificial groups that need an external force to sustain. The Catholic Church does not force anyone to get baptized; they baptize only those people who wish to get baptized. The reason for analyzing Army was that in most countries, it is mandatory for people to serve the Army.

In Brazil, people who are not baptized are considered to suffer with original sin, and those who refuse to serve in the Army, become second class citizens. They don't even get jobs because they do not get the most important citizenship document, the reservation certificate. Generally, there are several types of groups: Ephemeral or short-lived, lasting, homogeneous, natural as family, organized, and disorganized groups.

In both cases of the Army and the Church, an external force is required to maintain their cohesion. Therefore, we can assume that illusion, as well as the existence of a leader, who will love everyone equally in the strict sense, and not in the sexual sense, are factors that can guarantee the unity of these groups. In a Catholic Church, Jesus Christ is the one who loves all equally; all believers are equal for Christ, which, as a matter of fact is the replacement or is in unity with the Lord. Thus, "Verily I say unto you, In as much as you have done it unto one of the least of these my brethren, you have done it unto me"; means, "love your neighbor as yourself because all men are equal before the Lord, they are all put in a relation of brotherhood, sons of one Lord”.

In Army, the soldiers are considered equal to the Commander. When they realize themselves as equal, they start showing egalitarian relations between themselves. There is no discrimination among any soldiers; all privates are privates, all sergeants are sergeants, all lieutenants are lieutenants, etc.

If a private disrespects any sergeant, he will be disgraced by all his peers and not only by the sergeant. Another soldier will arrest him, so that he suffers the punishments for contempt, or because of the act, which can be regarded as a dishonor by his peers and may even end in his expulsion from the Army.

For illustration, we will use the case of Brazil's national football team; the moment when "the nation in cleats" enters the field to compete in the FIFA World Cup. Everyone must pay absolute obedience to the coach. The group must unite as soldiers, to defend their homeland. When one is ruled out, the contusion and the discourse between players remains exactly the same; at times, this can be a great loss, but the group "is united and focused on its goal”.

The individuals of the groups, which we are studying at the moment, i.e., the Church and the Army, face a "nice" crossroad. It is noted in these two artificial groups, each individual is connected on one hand by libidinal links to the leader (Christ, the Commander-in-Chief) and, on the other hand, with the members of the respective Group. It seems that we have found the right path for ourselves for an explanation of the main phenomena of the group psychology: the lack of freedom of an individual in a group. If every individual is tied in two directions by an intense emotional bond, then it is not so difficult to find any assignment to the circumstance, the amendment, and restrictions that are observed in his personality [1].

Thus, according to Freud [1], both the unity of a group and its disintegration can be assigned to existing libidinal ties, between the components, from the love of their leader. However, the loss of the leader in one way or the other and the suspicions arising from it cause panic. Although the risk remains the same, however, mutual ties between the group members generally disappear along with their ties with their leader.

In Army, we observe this phenomenon during a battle, often as a reaction of panic among the soldiers of a platoon. While fighting, they perform heroic feats, save, help, face atrocious dangers, and resist the most adverse conditions. However, if they lose their Commander in the fight and if there is no one else to occupy the place who deserves the same trust as the previous, then the platoon 
becomes disorganized, the members get disarticulated and finally they withdraw, no matter how many injured are left behind, or how much is the actual intensity of danger.

If this condition occurs after the death of the Commander, then it is likely that the emotional ties of the platoon must have been destroyed. The state of panic among the soldiers is not related to the danger itself, but rather to the anguish of the broken ties. These still exist where soldiers face situations involving dangers of great magnitude and still observe each other with a consideration and a spirit of mutual help. This, at last, helps to keep them together. According to Eros, if a group lives in lack of love, then the Group disappears and dies as a disarticulated group. Therefore, it is impossible to doubt that panic means the disintegration of a group; rather, it involves the cessation of all feelings of consideration, which the group members, in other respects, show toward each other [1].

Nowadays, we can see changes that are happening in most Arab countries; a movement known as the "Arab Spring”. However, one cannot predict what will replace the previous regimes, because there is no clear leadership and this absence of a leader or a government program can cause mobs to destroy the goodness that still exists.

\section{The Freudian Theory and Understanding of the Group Phenomenon}

We will continue our attempt to understand the Group phenomenon, generally using the theoretical resources of psychoanalysis, especially some Freudian formulations about it. We'll use the concepts of the Oedipus complex, identification, the theory of libido, and narcissism, as resources to unveil group processes, the formation of a group and its innards, especially as regards to their functioning.

While analyzing these two groups, we noticed that the emotional ties are crucial. In a Church, the identity-aware process maintains an object-oriented theme in parallel, since among Christians the mutual love is one of the conditions for being loved by the Lord. The mutual bonds become so much complicated, complex, and resistant because believers reproduce their emotional ties. Even if their faith is shaken or even if they criticize the Church or its dogmas, they can't break such ties and may even change their church or religion, to keep the same schemes and similar ties.

People often tend to form groups. They congregate at certain times and become propitious to tolerate each other and establish ties of friendship, which are only reaffirmed when intolerance is overlooked.

Another aspect of group life is found among families who have ties, such as matrimonial. They start to consid- er one family better than another. Everything that relates to one's relatives is much bigger and better; their history, their possessions, and their commitment to make their children happy. It is just like what happens between the partners of the same company, in which one always maintains some complaints about the other: one works more and the other is the one who causes hindrance.

All these are expressions of the ambivalence permeates human relationships, whose main flow is acceptable and remains conscious. The other chain, which nourishes complaints and considerations, nothing nice in relation to others, needs to stay away from consciousness and only explode when the reasons to keep it out of consciousness are eliminated. Another example is a fighting couple, who like and respect each other even while fighting. The other side of the relationship comes to the forefront, appears clear and limpid, and later only apologies can sometimes fix the damage. This way, this aspect of ambivalence in a group must be worked; if one side does not change, then the group cannot continue together.

Another condition of psychism that acts negatively on the formation of the group is linked with the narcissism. As we know, the primary narcissism determines an early state in which the child spends its entire libido in itself. The secondary narcissism determines a return to ego, of the withdrawn libido from its object investments [7-10]. Finally, the libidinal investment in a person itself, with the exclusion of investment on the other, puts narcissism against the grain of group formation. Narcissistic people hardly become part of a group, i.e., they do not invest for others, and other people, in turn, become un- sympathetic to them. For a group to exist, it becomes necessary for propitiated libidinal investments of inhibited ends and narcissism to occur because it is an investment in its own self and becomes opposite to the formation of the group. For group formation to occur, a demotion of narcissism in a broad way must occur, so that people can exchange and invest in each other, thus giving rise to emotional ties.

Another key factor, which is equally scathing in forming the group, is paying respect to identification. Identification can be understood as the psychological process by which an individual assimilates an aspect, a property, or an attribute of another and transforms totally or partially according to the person's model. Personality is constituted and differentiates itself by a series of identifications [7]. By the way, this is the more remote emotional bond that changes through an individual's psychic development and objective investment. Since a child is born, he identifies the objects around him. In summary, the baby first identifies the milk that it swallows. In this very concrete example, the child establishes his first bond with the milk. As the child grows, other objects 
serve for the identification process. However, dialectically, to the extent that an object becomes part of a child and of its ego, it is destroyed as being something independent of its existence. Self-identification is to become equal, and this implies a certain destruction of the identified object [11-13].

This way, the child will develop until the period of experiencing Oedipus complex, which, we will shortly address in order to understand how identification processes flow in the formation of a group. The boy in the Oedipus complex, in its positive version, identifies his father. With this, the cathexis or libidinal investment is directed to the mother. These two conditions, at first, become separated, until the father becomes or is conceived as an intruder, and the identification takes a hostile connotation. As he identifies his father, he takes the place of the father, getting rid of it. From anatomical differentiation between the sexes, which starts to have internal resonance in a child, appears the fear of castration. People are now perceived as different. The boy then, stops investing sexually on the mother, as it will appear as a forbidden object. The latency period comes to ease, temporarily known as the sexual life of the child. The child does not remain in the same way, in which it was as in oedipal living. Parents, who are target objects, are prohibited of libidinal investment so that the child can be educated, or better saying, socialized [2,3,8,12-17].

During adolescence, the tendency will be to resume libidinal investment and the objects will appear as the representatives of early childhood objects. Secondly, the boy can choose a girl for dating, or to love in an idealized way, for a mental or physical resemblance, to his own mother. And so, consequently we may have a separation from the sensual inhibited flow, affective, and love of sexual flow. The girl who is liked and worshipped won't be the target of sexual desire, because she is as pure as a saint, the Holy Mother. These can be either fleeting or not, but are consequences of the Oedipus complex [18-22].

As the idealized relationships become increasingly carnal, the exclusion of sex starts to disappear and the idealization becomes less intense. However, the need or desire for sex vanishes temporarily after its satisfaction. Therefore, a state has to exist till the time when the need occurs again with the object for satisfaction. So an investment in an object for a long time occurs in the states of passion and enchantment. Perhaps, the necessity of the formation of a family has been made by this condition, because keeping an investment at someone for a long time would guarantee that sexuality would have its satisfaction facilitated.

We know that, somehow, the end of the Oedipus complex, both boy and girl, establish a condition of inhibition of sexual impulses towards their parents. However, this fact intensifies the fondness and affection of relations. Often, the fondness and affection remain as possibility of expression only between family members; it is not unusual for a man to consider only his wife and his mother as saints, and devalue all other women, i.e. "doing everything with the other broad" and, with his wife, conforming to an aseptic pleasure [13,19,22].

Turning back to the formation of groups, we have seen the establishment of affective and emotional relationships, which are, by the way, inhibited ends or diverted from sexuality. But, where there is exclusively sexual interest among members, there is a great probability of group extinction. It is not a coincidence that the Catholic Church tries to abolish sexual interest, even though we know that this cannot practically happen. The army, until recently, had kept women away from their ranks. Sex and group formation in these two institutions seemed to be antagonistic things. Similarly, when a person likes, has affection or has consideration for someone, they both will try to preserve their intimacy as a couple. Since when the emotional ties become objectives of inhibited sexual ends, which would transform the libido into affection, there occurs the possibility of couple exchanging, or permissiveness, in which group sex could be the greatest manifestation.

Let's turn back to Oedipus complex. This is inverted or negative in concept as in the boy's case, he identifies his mother and his desire is directed toward his father, causing fantasy in the boy, taking the place of the mother and can configure a homosexual position of his sexuality $[2,19,20,23,24]$.

Often, the boy was keeping its libidinal investment in relation to his mother. However, when it comes to the Oedipus complex, his mother, as we have seen, becomes a banned object for him. But rather than taking the leap and finding a surrogate mother object, he identifies her and chooses someone to replace her in the relationship. Thus, he substitutes his own self and treats the other person as his mother treats him. In his fantasy, he becomes the mother, and chooses someone, psychically very similar to himself, to treat that person as a child [3].

With these theoretical examples, taken from the individual psychic dynamics, we intend to demarcate that when there is a sexual explicit flow, it becomes contrary to group formation. The same occurs with the existence of narcissism, as for a group to exist it becomes necessary for sexual and libidinal investments to occur with inhibition in its purpose. Otherwise, without these conditions we would not have ways to weave the delicate plot for group formation. Thus, we conclude that in order to have ties of affection, a loosening of narcissistic dynamics as well as a reduction of ambivalence should exist. Also, from the identification between persons, favored by a common ideal among them, we will find another condi- 
tion, which will be necessary and sufficient for the group formation.

Using other psychoanalysis resources, in relation to the human psychism, we will choose the neurotic states or neuroses, as one more of the ways, to understand the wealth of group phenomena.

Typically, neuroses are formed by an instinctual situation, in which an unconscious impulse seeking satisfaction or mental representation puts itself opposed to another part of the personality. As they mature, the actions, the impulses, and the desires of the person that are compatible with itself, at some earlier stage of their development, no longer exist. Often it becomes averse to his conscious personality, because this repertoire of tendencies, desires, and impulses may have been suppressed in some way, with the finality of keeping it away from consciousness. However, for various psychic dynamics reasons, repression may fail and at this time the return of the repressed, not exactly as it was before occurs. The failure of the repression does not mean the absence of this, but in a conciliatory way, disguised, as so to speak satisfies the conflicting parts of personality. This conciliation of the return of the repressed as a disguised way is called the symptom. The substitutionary formation designates the symptoms or equivalent formations, such as the so-called bungled acts, etc., while replacing the contents of unconscious. This substitution must be taken on a double meaning: economical, because the symptom causes a satisfaction of unconscious desire replacement, and symbolic, because the unconscious content is replaced by another, according to certain associative lines $[10,12,13,25]$.

For these authors, in the framework of the economic theory of libido, we can understand how a replacement occurs and its exchange by other satisfaction, which will also be linked to the reduction of tensions. But satisfaction cannot be seen as only qualitative, since psychoanalysis tells us that there is an association between the symptom and what it substitutes. The replacement then, starts to have, a symbolic sense since it results from displacement and from the condensation that will determine the symptom.

Thus, we can think that the more the compromise is by the neurotic personality conflicts, greater and more will be the replacements, leading the person to become intensely involved with himself and with its things, farther from reality, because the replacement, both economically and symbolically becomes increasingly predominant.

An obsessive neurotic, who washes his hands sixty times a day, or a very serious hysteric, who feels pain, blindness etc., will have a great difficulty to live in home or to socialize with others. However, as surprising as it may seem, for being the group formation and neurosis apparently incompatible, when a group is formed, an individual's disease, which belongs to this group, tends to disappear, at least apparently. The pain it felt before also disappears. The "miracle" starts to be consciously assigned to the group. It is not uncommon to hear people say that after attending a particular group or a particular religion the diseases have disappeared. This is certainly a group phenomenon. This happens in various groups in different religions. No group, no religion has the exclusivity of the disease disappearance phenomenon. So, if we know that the neurotic disease establishes itself by a replacement, which in turn enables the satisfaction of the repressed desire, we deduct that life group enables the satisfaction of impulses, halting the possibility of symptoms development.

According to Freud [2,15,26,27], the development of libido in children acquainted us with the first, but also the best example of inhibited sexual instincts in its objectives. All the feelings that a child has for his/her parents or for those who take care of him/her become, by an easy transition, desire, which gives expression to the child's sexual impulses. It claims the objects of love and all signs of affection it knows; wants to kiss them, touch them, watch them, are curious to see their genitals and be with them when they are performing their intimate, excretory duties, promises to marry the mother or the nanny without even understanding the meaning of marriage, proposes himself to have a child from a parent, etc. Direct observation, as well as the subsequent analytical research of childhood residue, leaves no doubt about the complete fusion of feelings, like being tender, jealous, or sexually attracted, showing us how essential a child makes a person he loves the object of all his sexual orientation. This first configuration of a child's love, which in typical cases takes the form of the Oedipus complex, succumbs, as far as we know from the beginning of the period of latency, to a wave of repression. What remains of it is a purely emotional and affectionate bond that pertains to the same people, but can no more be described as sexual attraction. Psychoanalysis, which illuminates the depths of mental life, has no difficulty in demonstrating that sexual links also persist in early childhood even though sexuality is then repressed and unconscious. Thus, we can say that an affectionate feeling, wherever found, is a successor of a binding object that is completely sensual with the person on the agenda or, rather, with the prototype (or imago). In this person, the inhibition of sexual objectives or instincts has a great advantage. Since, such people are not able to actually fulfill their satisfaction, they especially create permanent links, since their sexual instincts directly incur into a loss of energy whenever they satisfy and are expected to get renewed for a further accumulation of sexual libido.

Continuing with Freud's thinking [3,6], seeking to deepen our research on groups, we found that the psy- 
choanalytic investigation of psychoneuroses taught us that its symptoms should be connected directly to sexual impulses that are repressed, but remain active. We can complete this formula by adding in objective the inhibited pulse, whose inhibition has not been entirely successful or allowed a return of the repressed sexual objective. This agrees with the idea in which neurosis makes its victim asocial or a part of the usual group formation. We can say that neurosis has the same disintegrator effect on a group, as the state of being in love. On the other hand, it seems that where it is given a powerful impetus onto the formation of the group, neuroses can decrease or, at least temporarily disappear. Justifiable attempts were made, in terms of therapy, to situate this antagonism between the neuroses and the group formations. Even, those who do not mourn on the loss of religious illusions in today's civilized world recognize that as long as these illusions stay on demand they provide a more powerful protection against the danger of neurosis. It is not difficult to discern that all links, which bind people to mystical sectors and communities, and mystic-religious or philosophical-religious, are expressions of distorted cures of all neuroses kind.

Thus, it is not coincident that we find groups of all shapes and qualities, more or less organized, religious, political, and intellectual. Indeed, society as a whole can be considered a group. The group can be considered as a resulting condition for humanization. We can also say that an individual is a group in itself.

At some point in history, there must have been some influence that led humans to group themselves. The Constitution of the subject came to be then known as a corollary of another's presence. Freud [28], for example, got inspired by a Darwinism thesis that explained the formation of a human family, probably the first of the groups by displacement of representations of other groups that might have incurred [29,30].

Within this perspective, it seems that the man first lived in hordes, which assumes a state of the human family quite distinct from what we can find at other times in our phylogeny. The hypothesis is that one of the components of the Horde has taken control on it, perhaps violent, what is very close to other animals, especially among mammals. With this, the head of the primeval Horde controls the females and the other members of the Horde, prohibiting sexual intercourse between them. However, as sexual intercourse has been prohibited, by consequence, the direct satisfaction of the sexual impulse creates the possibility of inhibition and the displacement of their objectives, blocking even the possibility of ties. Such impediment would have taken by force, which constitutes a form of external repression that can enable the impulse inhibition.

However, one day, appalled by such prohibition, the "sons" gathered and killed the boss "father" of the Horde, shredding it and devouring it. After the assassination, the hypothesis positions the existence of a transitional period until a new state of affairs was established. This transition period, called gynaecocracy, marked the predominance of women in the Horde. However, all men of the Horde desired the woman. Many males needed to be neutered, so by the stronger, who went on to take the reins of the Horde, assuming he was the heir of the best features of the one murdered. But as everyone had eaten the corpse of the former leader, everyone began to have similar characteristics, becoming relatives or accomplice in some way. Its consequence was the requirement of exogamy, allowing sexual relations only with strangers, belonging to other hordes [31-34].

In today's family, despite the constant change of the role of women, they are structured psychologically, and the father who is the one that places limits and integrates the function of prohibition. By such paternal aspects in family structure and oedipal history, the father receives the hatred of his rival son, the competitor of maternal love. It is as if family with its current structure would repeat its prehistory. In addition, by approximation, the need for a leader in the groups would find have this explanation.

We find clues, which are reminiscent of the origin of the family from the transformation of the hordes, inside rituals of many groups of our days, as the ritual of communion in the Catholic Church, in which all drink the blood and eat the body of Christ, thus, by ingestion becoming brothers with the qualities that Christ had now within each of the church members.

These conditions can help us to diverge from the hypothesis in which men live in groups because of gregarious instinct and natural that would boost them to form such groups. One of the examples we can cite, contrary to the existence of a gregarious instinct hypothesis, is the behavior of young children. It is not unusual that when the child is left alone, depending on the need to have someone by its side, begins to cry, which would be proof of the existence of a gregarious impulse, which would cause it to try to approach others. However, the child cries, especially when the target of its libidinal investment is perceived as already missing. The child cries even more when someone stranger appears. This leads us to think that there is somebody who can satisfy it. It's not an instinct in itself, but rather, is an evidence that the objects needed by the child and by the people, who satisfy libidinal conditions and libidinal investments that could not be satisfied by others.

When we find someone in love, we realize that the target of its passion gains immense importance. One who is in love does not have any criticism in relation to one another. The object of passion is considered perfect and 
the passionate one places itself in a state of near servitude in relation to the object loved. The object is important because without it the subject cannot succumb. The other is totally idealized. In the passion states, it is like as if the other takes the place of the person's ideal of ego. Occupying the place of what the subject would like to be or have. Many times, the perfection that we imagine exists in another and may be a projection of our own narcissism.

The ideology of ego can be understood as the personality instance that results from convergence of narcissism (Idealization of the ego) and identifications with parents, with their replacements and cultural ideals. While being differentiated instantly, the ideal of ego constitutes a model to which the individual seeks to conform himself [7].

Our ideology of ego is very much variable. Some people have it very close to their reality from their conditions, which almost does not require anything from them. In some others, the ideal is very high, demanding critical judgment in relation to their achievements and to the things of its life. In the second case, we can say that if the demands are not paralyzing then we will have the possibility of seeking uninterrupted growth and achievement. A less critical judgment states that anywhere almost anything can be required.

In cases of psychogenic depression, we can observe that the person criticizes himself mercilessly. When saying "so-and-so, you are not the worst person in the world"; He, not satisfied with our approach, defends his self-depreciation, saying that the observation is a pure kindness of us. Then, all the misfortunes that depressed the subject delegate himself, all the exaggeration of its self-assessment, suggest that he probably is attacking someone alike, which it is identified. The complaint, addressed to the object, demands for this identification and becomes claims and complaints addressed to itself [3, 8-10,12,13,25,26,35].

Personal evaluations are always upwards but never downwards under any circumstances, but self-criticism around its real possibilities are very superficial. By exaggeration, by exacerbation, or inflation of its own, we can say that the maniac subject somehow fuses with its ideal of ego [36].

Applying such knowledge regarding the group formation, we notice that a person inserted in a group feels strong, solves all things, and can face the world. Somehow, it also replaces its ideal of ego by another object, for example the leader, and identifies itself with the other members as they also replaced their ideal of ego for the same object. Thus, the ideals of the group become the ideal of the subject and the subject does not measure efforts to comply with the requirements of the group, which also started to be of his.
This identification allows us to understand of how the person undergoes major changes when inserted into a group; this is how the group exercises a decisive influence on the individual personality, much like what we see in the phenomena of hypnosis. In hypnosis, the hypnotist, in order to repeat a monotonous movement and ask the person for his whole attention, makes the world totally uninteresting. If, at that moment only the repetitive movement exists, then this, as the only thing in the world, becomes its representative, and the world, so monotonously represented, delegates considerable importance to the hypnotist.

Every night, in order to fall asleep, we remove all stimuli from our senses and our thoughts. We almost always do the same thing, "sing every night, almost the same way, our very private lullaby". But in hypnosis, the hypnotist monotonously suggests the hypnotized: "the world is unattractive; you only have to pay attention to me, because I am the most important person in this monotone world”. However, in hypnosis the order to sleep means, neither more nor less, an order to keep away from the world all interest and focus it in the person who is a hypnotist. It is well understood by the subject because in this retraction of interest from the outside world, is the psychological characteristic of sleep and in it is based the relationship between this and the state of hypnosis [16].

The hypnotist says: "only watch me, because the world is totally uninteresting”, the other will never be hypnotized. Similarly, in a group the leader never says, "Look I am your idealized portion; you will admire me, as a God, as someone you would like to be.” In these cases, everything happens in a surreptitious manner, almost imperceptible, based on the phenomenon of identification. In the case of groups, the leader is usually the one who is elected and has autonomy of action as the remainder lacks, but, being a figure, which replaces the ideal of all members, all members identify themselves, from their ideal, with each other.

The phenomenon of identification can be observed in various group situations. It is not uncommon in families where one of the components dies, rather one of the closest relatives will develop the disease that the one who died, to be identified with the deceased [11,37-42].

In "Sexuality in the Aetiology of the Neuroses" [43], we find the report of a case of a patient who is developing the same symptoms of the father, because somehow the object's choice is regressed to identification. Rather than wishing to be the father, the patient becomes the father.

In another example of the identification process, Freud himself, reports the case of a girl who inside the boarding school falls in love and tells her secret to other girls. The girl is becomes ill and her confidantes, as a process of infection, start to develop the same illness. For the first, 
as to the other, the disease was a way to get out of the school. The other colleagues identified with that and became ill, in her illness, so they fulfill the desire to have a person to love.

Contributions to the group theory and functioning of the group mind, is of course not only restricted to ideas of Freud and psychoanalysis.

Nowadays, the dynamical systems theory (DST), developed in mathematics and physics, provides a new perspective on the dynamics and complexity of the group phenomena. A dynamical system can be broadly defined as a set of interconnected elements, which undergoes change. The task of the DST is to describe the connections among a system's elements and changes in the system's behavior for which the connections arise [44].

Rouanet [34] pointed out that the philosophical thoughts of Nietzsche and Schopenhauer, amongst others, presented formulation in relation to unconscious, i.e., a deep awareness that found another ego. Thus, Freud started enhancing this concept and taking it to the center of his theory, describing its operation, laws, and allowing man to have an expanded vision of himself, i.e., the loss of illusion that one can have everything under his own control.

However, the term unconscious is used in different manners by many psychoanalysts. As a noun, it designates a "locus" that is defined by opposition to the conscious, despite the fact that, even with the current neuroscience studies, there is no place in the mind corresponding to the same [45]. As an adjective, the term unconscious is related more closely to the second topic, which is used much more as a quality of contents of ego, superego, and id. The use of the term, associated with the idea of process and function, related to specific forms of the mind, is also observed [46].

The dynamic aspect of the unconscious qualifies a perspective that considers the psychic phenomena as resulting from the conflict and the composition of forces that exert a certain pressure and force that are, in an ultimate analysis, of pulsing origin [7]. More recently, Procci described the unconscious as a chaotic and deterministic system, following some epistemologists of modern science [47].

In the analysis of Santos [48], the current scientific thought exists is an astonishing way and in a transition time in which the rationality model no longer responds to the demands of knowledge. The rationality model seeks laws that are learned from observation and experimentation that could be mathematically represented and understood in a clear and simple manner, and from which a more deeper and accurate knowledge of nature could be reached. This simplistic reduction of the traditional science considers the appearance of a contradiction as a sign of a logic error, as it conceives that the world is ruled by universal laws. However, among other factors, the studies of Prigogine [49] revolutionized the principle of thermodynamics. The thermodynamic theory of dissipating structures and the principle of order through fluctuations establish that evolution is explained by energy fluctuations in open systems, i.e., systems that operate in stability margins. This means that reactions are spontaneously triggered in certain moments, i.e., moments that are never fully predictable. Thus, such moments, by means of non-linear mechanisms, push the entire system to beyond a maximum limit of instability and lead it to a new macroscopic state. This irreversible and thermodynamic transformation results from the interaction of microscopic processes, following a self-organizing logic in a non-balance situation, and thus allowing the appearance of new complex organizations from the disorder.

Abrams and Sardar [50] used the deterministic theory of chaos to elucidate the functioning of various complex systems, showing that the disorder of the system could only be apparent when a disorder, without periodicity, rules systems that are considered as fully random. Also, deterministic causes could originate from unforeseeable effects, since one of the characteristics of the complex system is its sensitiveness and dependence on the system's initial conditions.

To Prigogine, the chaos theory deals with systems. It explains that, if on one hand systems obey the fundamental laws of physics, then on the other hand, are unforeseeable due to the great degree of diversity that they present. Complex systems need a large expenditure of energy to keep themselves cohesive as they pass through a chaotic period. The systems seek a redefinition, i.e., self-organization in their internal structures, which advances the whole system to a new organizational level [49,51].

Thus, in this way, the unconscious functioning models, as those found in the formation of groups, especially in the identification, influence the behavior, following juvenile standards, which could be considered as attractors. When thinking on the functioning of groups, the deterministic chaos theory model evidences the aspect of a continuous oscillation between the disorganized, chaotic material, not perceptible by its components, and an organization, which standards that, although maintaining a certain similarity with the original, could be creative to the infinite. Therefore, moments of chaotic disorganization also occur in group processes in which behaviors and actions could seem senseless until something occurs that can organize it to another level. Groups can thus, be thought as complex systems with characteristics of deterministic chaotic systems. Although some psychoanalysis schools continue to be concerned with reasons and causes of a group's form of being and acting, as well as the psychic structuring of individuals, however, it is also 
noticed that they currently seek to emphasize more and more on the indetermination and unforeseen circumstances of the psychological processes, i.e., circumstances that are understood as a characteristic of the chaotic and deterministic systems.

The subject matter of the group psychology poses as one of the most difficult challenges for any scientific explanation because human thoughts, feelings, and behaviors are inherently dynamic. Emotions show enormous fluctuations, thoughts flow in a stream of consciousness, and both individual and group actions are defined in terms of coordinated patterns of change. The group psychological dynamics depend on numerous external factors and internal workings of often elusive psychological mechanisms. The phenomena of group psychology are remarkably complex. The set of possible states and behaviors of an individual is complex enough in its own right and the interdependences of different individuals increase such complexity in a multiplicative manner [44].

The relationship between any two variables of a linear system can be described independently of the relations involving any of the other variables. This means that the relations are additive with the behavior of the system and as a whole they reflect the joint effect of separate relations. However, in a nonlinear system, the relationship between any two variables often depends on the current values as well as on other variables of the system. Unlike a linear system, a nonlinear system cannot be decomposed into separate additive components. This feature of nonlinear dynamical systems makes them difficult to ignore effects of other variables thus, describing the relation between variables of interest. Simultaneously, changes in any variable of the system tend to reveal the influence of the changes on all other variables of the system. Because of this effect, repeated observations of even a single variable may be informative regarding the structure of the whole system [52-54].

The trajectory of a dynamical system can visit points corresponding to many combinations of coordinates, in its early evolution. After some time, the trajectory of dissipative systems occupies less volume of the phase space, visiting only subset of points during its further evolution. This subset of points is referred to as the system's attractor. One might say that an attractor "attracts" all trajectories in a phase space because all trajectories eventually converge on the attractor, regardless of the system's starting point. Four classes of attractors have been commonly distinguished: fixed-point, periodic, quasi-periodic, and chaotic [55,56].

A fixed-point attractor describes a system in which all trajectories tend to converge to a single point in the phase space, regardless of the system's starting point. This means that the set of all dynamical variables converge on some set of time-independent constant values corresponding to an equilibrium point for the system. The particular attractor reached depends on the initial conditions. In such situations, the task is to describe the set of initial conditions leading to each of the system's stable points. All initial conditions that lead to a given stable attractor are called basins of attractions [55,57].

For Newtson [58], the temporal evolution of a system may also be governed by superimposition of different periods. This form of periodicity is referred to as the multipertiodic evolution. The most complex case of the multiperiodic evolution is the quasi-periodic evolution, in which each of the system's variable exhibits different periods, and these periods are incommensurable. In such instances, values of all variables get repeated with some period, but the system as a whole never returns to exactly to the same value.

The excitement in science, associated with nonlinear dynamics, is largely due to the discovery that the longterm behavior of a non-linear dynamical system may exhibit yet another type of behavior, referred to as chaotic evolution. Radical changes in a behavioral pattern are usually called bifurcations. They are sometimes even referred to as dynamical phase transitions or critical phenomena. Significant changes in patterns usually follow a small set of well-defined rules. One can even speak of changes in behavioral patterns. The classification of bifurcations is the focus of the catastrophe theory $[59,60]$.

The widespread fascination with chaotic systems is tied to the realization that although such systems are deterministic, however, they may be totally unpredictable in practice. This seemingly paradoxical state of affairs reflects the sensitivity to initial conditions (STIC) of nonlinear systems. In modeling weather fronts, Lorenz [61] found that even slightest changes in initial conditions, such as rounding the initial ambient temperature and humidity to the third decimal point, eventually led to entirely different patterns in his weather system. More generally, anything short of infinite precision in one's knowledge of a system at one time can undermine the knowledge of future states of the system. This is because all initial inaccuracies are amplified by the system's intrinsic dynamics such that the inaccuracies grow exponentially with time. Such exponential growth guarantees that after some finite time, the size of the error will be greater than the possible range of states of the system's behavior [44].

Chaos does not mean an absolute disorder or complete loss of form; it means that systems, which are guided by certain types of laws are perfectly ordered and capable to behave in a random manner and, thus, completely unpredictable in the long run, at a specific level. Moreover, this also presents a random behavioral pattern or a hidden order in a more general level. The chaos and the creative 
individual variety is within a general pattern of similarity [62].

In groups, the identification through the desire for one same object also seems to be in a common place, even in those of almost any organization. It is the case of U2, Oasis fans, and even in organized groups with a strong religious connotation and ideology, such as Al-Qaeda or Hamas. These are groups whose desires are directed toward the same target; they identify themselves and start to clump as they desire the same object.

The existence of a strong identification around a feature or a common desire can be observed here. Thus, the formation of ties appears from this condition that may result in the formation of a group.

\section{Final Considerations}

In the study of Group Psychology and the Analysis of the Ego, Freud considered the relationship between the group and its leader as a starting point. Freud located the essence of these relations in identification mechanisms. In fact, group processes may be linked to the most primitive forms of behavior as identification in psychoanalysis is considered as the earliest expression of an emotional attachment to another person.

This study reconsidered two cases analyzed by Freud: the Army and the Church, and some related concepts, such as paradigmatic examples for the analysis of the group phenomena of the contemporary society.

Most of the phenomena that we observe in nature and human behavior have characteristics of order and stability on one side, and disorder and irregularity on the other side. Groups are unpredictable and uncontrollable, and are subject to external and internal disturbances that operate under conditions of risk and uncertainty, with incomplete or limited information. Although embedded in a turbulent environment, groups traditionally use decision making models that are based on assumptions of predictability, rationality and control. The consideration of alternative theories to the traditional thought and Cartesian mechanistic interpretation is another option offered to psychologists for a better understanding of complex dynamic systems, such as those that occur in groups.

The concepts formulated by Freud and the whole theoretical framework of psychoanalysis are thus not yet exhausted. We can test them in many ways, not only in laboratories, but also for understanding the globalized world and its impact on nations, behavior, and groups that are formed with different goals. Therefore, the globalized world has never been so different.

\section{REFERENCES}

[1] S. Freud, "Group Psychology and the Analysis of the
Ego," The Standard Edition of the Complete Works of Sigmund Freud, Vol. 18, The Hogart Press, London, 1974, pp. 67-143.

[2] S. Freud, “Three Essays on the Theory of Sexuality,” The Standard Edition of the Complete Works of Sigmund Freud, Vol. 7, The Hogart Press, London, 1947, pp. 125-245.

[3] S. Freud, "The Ego and the Id," The Standard Edition of the Complete Works of Sigmund Freud, Vol. 19, The Hogart Press, London, 1974, pp. 3-66.

[4] S. Freud, "Civilization and Its Discontents,” The Standard Edition of the Complete Works of Sigmund Freud, Vol. 21, The Hogart Press, London, 1974, pp. 59-145.

[5] S. Freud, "The Psychogenesis of a Case of Homosexuality in a Woman," The Standard Edition of the Complete Works of Sigmund Freud, Vol. 18, The Hogart Press, London, 1974, pp. 147-172.

[6] S. Freud, "The Future of an Illusion,” The Standard Edition of the Complete Works of Sigmund Freud, Vol. 21, The Hogart Press, London, 1974, pp. 3-56.

[7] J. Laplanche and J.-B. Pontalis, "Vocabulário de Psicanálise,” Martins Fontes, São Paulo, 1983.

[8] D. Meltzer “The Psycho-Analytical Process,” Karnac, London, 2008.

[9] R. Mezan, "Freud: A Trama dos Conceitos,” Perspectiva, São Paulo, 1982.

[10] H. Nunberg, "Principles of Pscyhoanalysis,” International Universities Press, New York, 1989.

[11] M. Klein, P. Heimann and R. E. Money-Kyrle, "Temas de Psicanálise Aplicada,” Zahar, Rio de Janeiro, 1969.

[12] D. Meltzer, “Sexual States of Mind,” Karnac, London, 2008.

[13] T. H. Ogden, “Subjects of Analysis,” Karnac, London, 1994.

[14] J. Brunner, "Oedipus Politicus: O Paradigma Freudiano das Relações Sociais,” In: M. S. Roth, Ed., Freud Conflito e Cultura, Jorge Zahar, Rio de Janeiro, 2000, pp. 76-86.

[15] S. Freud, "Civilized Sexual Morality and Modern Nervous Illness," The Standard Edition of the Complete Works of Sigmund Freud, Vol. 9, The Hogart Press, London, 1974, pp. 179-204.

[16] S. Freud, "Some Psychical Consequences of the Anatomical Distinction between the Sexes," The Standard Edition of the Complete Works of Sigmund Freud, Vol. 19, The Hogart Press, London, 1974, pp. 243-258.

[17] S. Freud, "New Introductory Lectures on Psycho-Analysis," The Standard Edition of the Complete Works of Sigmund Freud, Vol. 22, The Hogart Press, London, 1974, pp. 3-182.

[18] A. Aberastury, "Psicanálise da Criança: Teoria e Técnica,” Artes Médicas, Porto Alegre, 1982.

[19] P. Blos, “Adolescência: Uma Interpretação Psicanalítica,” Martins Fontes, São Paulo, 1985.

[20] E. Kalina "Psicoterapias de Adolescentes. Teoria, Técnica e Casos Clínicos,” Artmed, Porto Alegre, 1999.

[21] D. L. Levisky, “Adolescência: Reflexões Psicanalíticas,” Casa do Psicólogo, São Paulo, 1998.

[22] D. Meltzer, “The Claustrum: An Investigation of Claus- 
tophobic Phenomena,” The Roland Harris Education Trust, London, 1992.

[23] S. Freud, "Analysis of a Phobia in a Five-Year-Old Boy," The Standard Edition of the Complete Works of Sigmund Freud, Vol. 10, The Hogart Press, London, 1974, pp. 3-149.

[24] S. Freud, "Beyond the Pleasure Principle," The Standard Edition of the Complete Works of Sigmund Freud, Vol. 18, The Hogart Press, London, 1974, pp. 7-64.

[25] G. O. Gabbard, "Psychodynamic Psychiatry in Clinical Practice,” American Psychiatric Publishing, Washington DC and London, 2005.

[26] S. Freud, "Mourning and Melancholia," The Standard Edition of the Complete Works of Sigmund Freud, Vol. 14, The Hogart Press, London, 1974, pp. 239-258.

[27] S. Freud, "Female Sexuality," The Standard Edition of the Complete Works of Sigmund Freud, Vol. 21, The Hogart Press, London, 1974, pp. 223-243.

[28] S. Freud, “Totem and Taboo," The Standard Edition of the Complete Works of Sigmund Freud, Vol. 13, The Hogart Press, London, 1974, pp. 1-161.

[29] H. P. Blum, "Da Sugestão ao Insight, da Hipnose à Psicanálise,” In: M. S. Roth, Ed., Freud Conflito e Cutura, Jorge Zahar, Rio de Janeiro, 2000, pp. 87-95.

[30] J. E. Toews, “Ter e Ser: A Evolução da Teoria Freudiana do Édipo Como Fábula Moral,” In: M. S. Roth, Ed., Freud Conflito e Cultura, Zahar, Rio de Janeiro, 2000, pp. 63-75.

[31] E. Fromm, "Psicanálise da Sociedade Contemporânea," Zahar, Rio de Janeiro, 1961.

[32] I. Grubrich-Simitis, "Nada Sobre a Refeição Totêmica: Sobre as Anotações de Freud,” In: M. S. Roth, Ed., Freud Conflito e Cultura, Jorge Zahar, Rio de Janeiro, 2000, pp. 23-34.

[33] H. Marcuse, "Eros and Civilization. A Philosophical Inquiry into Freud,” Beacon Press, Boston, 1966.

[34] S. P. Rouanet, "Mal-Estar na Modernidade," Companhia das Letras, São Paulo, 2001.

[35] T. H. Ogden, “This Art of Psychoanalysis: Dreaming Undreamt Dreams and Interrupted Cries,” Routledge, London, 2005.

[36] O. Fenichel, “Teoria Psicanalítica das Neuroses,” Liv. Atheneu, Rio de Janeiro-São Paulo, 1981.

[37] J. Bleger, “Temas de Psicologia,” Martins Fontes, São Paulo, 1989. http://dx.doi.org/10.1037/0003-066X.49.1

[38] L. Grinberg, D. Sor and E. T. de. Bianchedi, "Introdução às Idéias de Bion,” Imago, Rio de Janeiro, 1973.

[39] R. Kaes, “O Grupo e o Sujeito do Grupo. Elementos para uma Teoria Psicanalítica do Grupo,” Casa do Psicólogo, São Paulo, 1997.

[40] R. Mucchielli, “La Dinamica de los Grupos,” Iberico Europea de Ediciciones, Madrid, 1969.

[41] M. E. L. da. Silva, "Pensando o Pensar com W. R. Bion," MG Editores, São Paulo, 1988.

[42] D. E. Zimerman, "Manual de Técnica Psicanalítica. Uma Re-Visão,” Artmed, Porto Alegre, 2004.
[43] S. Freud, "Sexuality in the Aetiology of the Neuroses," The Standard Edition of the Complete Works of Sigmund Freud, Vol. 3, The Hogart Press, London, 1974, pp. 261285.

[44] R. R. Vallacher and A. Nowak, "The Emergence of Dynamical Social Psychology,” Psychological Inquiry, Vol. 8, No. 2, 1997, pp. 73-99. http://dx.doi.org/10.1207/s15327965pli0802_1

[45] C. Paniagua, “The Attraction of Topographical Technique,” International Journal of Psychoanalysis, Vol. 82, No. 4, 2001, pp. 671-684.

[46] I. Matte Blanco, “The Unconscious as Infinite Sets,” Duckworth Press, London, 1975.

[47] W. Procci, "Panel Report: Chaos Theory as a New Paradigm in Psychoanalysis," International Journal of Psychoanalysis, Vol. 83, No. 2, 2002, pp. 487-490.

[48] B. S. Santos, "Um Discurso Sobre as Ciências," Afrontamento, Porto, 1993.

[49] I. Prigogine "O Fim das Certezas-Tempo, Caos e Leis da Natureza,” UNESP, São Paulo, 1996.

[50] I. Abrams and Z. Sardar, "Introducing Chaos,” Totem Books, USA, Icon Books, 1998.

[51] S. Barton, "Chaos, Self-Organization, and Psychology," American Psychologist, Vol. 49, No. 1, 1994, pp. 5-14. 51

[52] P. Grassberger and I. Procaccia, "On the Characterization of Strange Attractors,” Physical Review Letters, Vol. 50, No. 5, 1983, pp. 346-350. http://dx.doi.org/10.1103/PhysRevLett.50.346

[53] D. T. Kaplan and L. Glass, "Direct test for Determinism in a Time Series,” Physics Review Letters, Vol. 68, No. 4, 1992, pp. 427-430. http://dx.doi.org/10.1103/PhysRevLett.68.427

[54] F. Takens, "Detecting strange Attractors in Turbulescence," In: D. A. Rand and L. S. Young, Eds., Lecture notes in mathematics, Vol. 898, Springer, New York, 1981. pp. 366-381.

[55] J. P. Eckmann, and D. Ruelle, "Ergodic Theory of Chaos and Strange Attractors," Review of Modern Physics, Vol. 57, No. 3, 1985, pp. 617-656.

[56] H. G. Schuster, “Deterministic Chaos,” Physik Verlag, Vienna, 1984.

[57] D. M. Buss, "Evolutionary Psychology: A New Paradigm for Psychological Science,” Psychological Inquiry, Vol. 6, No. 1, 1995, pp. 1-30. http://dx.doi.org/10.1207/s15327965pli0601_1

[58] D. Newtson, "The Perception and Coupling of Behavior Waves,” In: R. R. Vallacher and A. Nowak, Eds., Dynamical Systems in Social Psychology, Academic Press, San Diego, 1994, pp. 139-167.

[59] T. Poston and I. Stewart, "Catastrophe Theory and Its Applications,” Pitman, Boston, 1978.

[60] R. Thom, "Structural Stability and Morphogenesis," Addison-Wesley, New York, 1975.

[61] E. Lorenz, "Deterministic Nonperiodic Flow," Journal of Atmospheric Science, Vol. 20, No. 2, 1963, pp. 130-141. 
http://dx.doi.org/10.1175/1520-0469(1963)020<0130:DN $\mathrm{F}>2.0 . \mathrm{CO} ; 2$

[62] R. D. Stacey, "Strategy as Order Emerging from Chaos,"
Long Range Planning, Vol. 26, No. 1, 1993, pp. 10-17. http://dx.doi.org/10.1016/0024-6301(93)90228-8 